\title{
特 許
}

\begin{tabular}{|c|c|c|c|c|c|}
\hline $\begin{array}{l}\text { 公告 } \\
\text { 番号 }\end{array}$ & 発明の名称. & 嫄 & 3662 & $\begin{array}{l}\text { 荻素の酸化物と水素との } \\
\text { 混合物よりタン製造 }\end{array}$ & 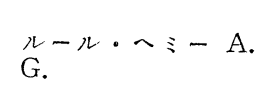 \\
\hline 3262 & 岑麦質電極の改良製造法 & $\begin{array}{l}\text { ュニオン・カーバイ } \\
\text { ド\&カーボン }\end{array}$ & 3663 & ク口ロエチレンの製造方 & ダウ・ケミカル Co. \\
\hline 3268 & $\begin{array}{l}\text { フェノール采化合物の製 } \\
\text { 造方法 }\end{array}$ & ダウ・ケミカ ル & 3678 & 冈外侏熱式流動乾溜方法 & 工業技術院長 \\
\hline 3271 & タール䧥炭の製造法 & 喜 多 信 元 & 3679 & $\begin{array}{l}\text { 固形燃料用粘結着火剂の } \\
\text { 製造 }\end{array}$ & 小野沢 辰五 郎 \\
\hline 272 & ガス円の硫化水素除去法 & 東洋高圧工業(株) & & & \\
\hline 273 & エアーガスの発生装置 & 山根 良 本 & 3680 & & 同 \\
\hline & 石炭類の流動乾溜方法 & 工業䔩峴院長 & 3681 & 原油の蒸発䏚止法 & $\begin{array}{l}\text { スタンダード・オイ } \\
\text { ル }\end{array}$ \\
\hline & 生成物に変损 & テ キ サ & 3682 & $\begin{array}{l}\text { 阥火㷄瓦表面の耐熱塗装 } \\
\text { 方法 }\end{array}$ & 含思貢ほ か \\
\hline 77 & $\begin{array}{l}\text { 念有物啠上り原油を分離 } \\
\text { する改良法 }\end{array}$ & G. R. クールソン & 3692 & 不飽和化合物の重合方法 & バ タ - フ \\
\hline 3278 & $\begin{array}{l}\text { 触媒の定期的雨·生による } \\
\text { 焱化水素の接触的処理法 }\end{array}$ & バターフセ & & は重合方法 & コッパースCo. \\
\hline 3351 & $\begin{array}{l}\text { 洆汽発生機用の日㓰制御 } \\
\text { 裝置 }\end{array}$ & $\begin{array}{l}\text { ベーバー・ヒーヒー Corp. } \\
\text { ング }\end{array}$ & 3773 & 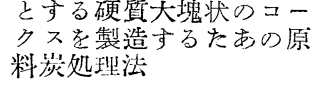 & 三菱化成工業(箖) \\
\hline & 洆汽発生及加熱装置 & $\begin{array}{l}\text { C. E. Inc. } \\
\text { タ.モンド・ケ }\end{array}$ & 3775 & 石炭の低䀀処理法 & 富土製 鉄(株) \\
\hline & & ル & 3776 & & 悲上 清 人 \\
\hline & 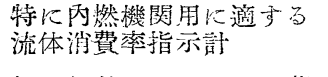 & $\begin{array}{l}\text { エス・アー・セー・・ } \\
\text { ウー・エム }\end{array}$ & & & \\
\hline 392 & 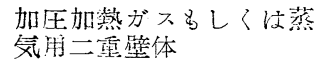 & $\begin{array}{l}\text { A. G.フェア・テク= } \\
\text { ッェスッデイェン }\end{array}$ & 3779 & 内燃機関用潤滑剂 & $\begin{array}{l}\text { 東洋高圧工澲(株) } \\
\text { シェル・レサーチLtd. }\end{array}$ \\
\hline 393 & $\begin{array}{l}\text { 液体燃料特に油燃燒汽缶 } \\
\text { の点火装置 }\end{array}$ & $\begin{array}{l}\text { スミッフォンク・テ } \\
\text { ームルーゼベヌーチ } \\
\text { ヤップ }\end{array}$ & $\begin{array}{l}3831 \\
3913\end{array}$ & $\begin{array}{l}\text { スチーム・トラップ } \\
\text { 流動反応方法 }\end{array}$ & $\begin{array}{l}\text { 滕原勝司㾜加 } \\
\text { 信越化学工業(株) }\end{array}$ \\
\hline $\begin{array}{l}\text { (抗) } \\
3412\end{array}$ & 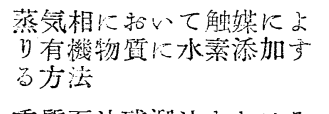 & $\begin{array}{l}\text { レ・ジュジーヌ・ド } \\
\text { メル }\end{array}$ & 3914 & 炭茲犋霆䄚 & $\begin{array}{l}z=\text { オ・カーバイ } \\
\text { 卜\&カーボン }\end{array}$ \\
\hline 432 & $\begin{array}{l}\text { 重啠石油殘测油末たはそ } \\
\text { の類似物のコークス化法 }\end{array}$ & $\begin{array}{l}\text { スタンダード・オル } \\
\text { イル }\end{array}$ & 3925 & 蒸溜物 & バ ターフ \\
\hline 3433 & $\begin{array}{l}\text { 流動化固体技術による获 } \\
\text { 化水素類の転化方法 }\end{array}$ & 上 & 3926 & $\begin{array}{l}\text { ハイドロフ } \\
\text { 改良 }\end{array}$ & $\begin{array}{l}\text { エッソ・リサーチ～} \\
\text { エンヂニアリング }\end{array}$ \\
\hline 523 & $\begin{array}{l}\text { 声火容易な有孔制竾の製 } \\
\text { 造方法 }\end{array}$ & 㧛 重 嘉一 & 3927 & ラフイン連 & 三悲 石 油(株) \\
\hline 3524 & 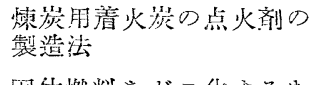 & 小野沢 辰五部 & 3933 & 耐火留被徣材 & 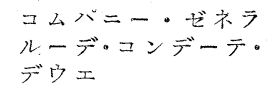 \\
\hline 52 & $\begin{array}{l}\text { 固体然料をガス化するた } \\
\text { め発生炉 }\end{array}$ & バワー・ガス Corp. & 3988 & 汽年給水 & 黍上政 次 \\
\hline & 複電橋式ガス分析話 & 工業技術院長 & 4050 & 濃虔 & 湑 水 䛧 \\
\hline & $\begin{array}{l}\text { 装犆の給水設備 } \\
\text { ビン機関の } 2 \text { 次 }\end{array}$ & A. G. スルツア & 4052 & $\begin{array}{l}\text { 帒発生譏に } \\
\text { 水との分離 }\end{array}$ & $\begin{array}{l}\text { ラ・モント・3 } \\
ル\end{array}$ \\
\hline
\end{tabular}

